\title{
Measurement of paraoxonase and telomerase enzymes and HDL (high density lipoprotein) values and research of their possible relationships with each other in bloodserum of obese cats
}

\author{
Tuğçe Dağ ${ }^{1}$, Şima Şahinduran ${ }^{1}$ \\ ${ }^{1}$ Department of Internal Medicine, Faculty of Veterinary Medicine, Burdur Mehmet Akif Ersoy University, Burdur/TÜRKIYE
}

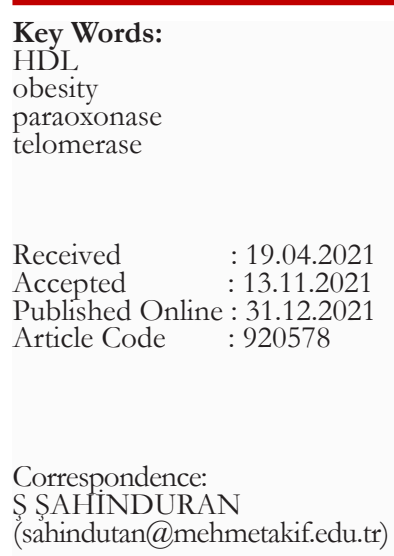

ORCID:

T DAG : 0000-0003-3486-2222

\begin{abstract}
Today, obesity is seen as a serious health problem in domestic cats. Paraoxonase1 (PON1) is a negative acute phase protein with anti-inflammatory properties. PON1 is transported by linking to different parts of HDL in the blood and has a protective feature of HDL against oxidation. Telomerase is reverse transcriptase enzyme that synthesizes and protects telomeres. Telomere length becomes shorter due to stress, obesity, and lack of exercise. In this study, paraoxonase1, telomerase enzymes and HDL values in blood serum of obese and non-obese cats were measured and their relationships with each other were evaluated. Body fat ratio in cats with body fat measurement system, those above $30 \%$ were evaluated as obese, and those below 30\% were evaluated as the control group. Paraoxonase1 ( $<<0.001)$, telomerase $(\mathrm{p}<0.001)$ and HDL $(\mathrm{p}<0.008)$ values showed a statistically significant difference between the both groups, it was found to be lower in the obese group compared to the control group. As a result; paraoxonase1 and telomerase enzymes which are parameters of oxidative stress and are known to decrease in inflammation, were also found to be decreased in obese cats. The fact that HDL values are lower than the control group is an indicator that there are diseases that occur together with obesity.
\end{abstract}

\section{INTRODUCTION}

Gastrointestinal Recent reports show that obesity is a growing problem in domestic cats, with approximately $25 \%$ to $40 \%$ of domestic cats being overweight or obese $(1,2)$. Since obesity is associated with some diseases in cats (eg diabetes mellitus, hepatic lipidosis, osteoarthritis, etc.), identifying the population at risk is a very important step. Various risk factors for obesity in cats have been identified in the literature; These are sex, neutering status, middle and old age, living in a single or two-cat house, inactivity indoors, feeding with fresh meat or fish, feeding with a first-class or therapeutic food, free choice or providing food on an ad libitum basis, and It is an underestimation of body weight or body condition by its owners (3). Many traits associated with obesity may be involved in the development of an inflammatory condition, even if the link between them is still not fully understood (4). Paraoxo- nase is an esterase that has arylesterase as well as aryldialkyl phosphatase activity. It is known that parathion, an organically phosphorous insecticide synthesized in the liver, has the ability to hydrolyzed the active metabolite paraoxon (5). The paraoxonase gene family consists of three enzymes PON1, PON2 and PON3 (6). PON1 has been reported to be a calcium-dependent serum esterase synthesized exclusively in the liver and found in the bloodstream associated with HDL. It has also been reported that PON1 prevents the accumulation of oxidized lipids in LDL (7).

While preventing the oxidation of HDL, it provides protection for PON1 to fulfill its functions at the same time. It is known that HDL inhibits lipid peroxidation in LDL and PON1 enzyme, which it primarily carries in its structure, is effective in this antioxidant effect (6). Paraoxonase type 1 (PON1) has anti-inflammatory properties, and its circulatory 
concentration has been reported to be reduced in human obesity subjects (8). In sheep and humans, PON is known to bind to different regions of HDL and is transported on HDL via apolipoprotein A1 (Apo A1). The role of PON in the antioxidant effect of HDL has recently paved the way for important studies to determine its role in the diagnosis and treatment of various diseases (9).

Telomerase is an enzyme that has the ability to synthesize itself by using its own RNA (Ribo Nucleic acid) as a template and has a ribonucleoprotein structure that has the task of extending telomeric DNA by adding hexomeric parts [(TTAGGG) n] to chromosomal ends, balancing and protecting the loss in chromosomal ends. In cancer cases, when the telomerase activity and telomere length of the cell were examined, it was seen that tumor formation and telomerase activity were interrelated in vivo (10). Various studies have been conducted in order to clarify the relationship between telomerase enzyme and immune system. In these studies; Enzyme levels were found to be low in $\mathrm{T}$ and $\mathrm{B}$ lymphocytes, and the presence of enzyme activity in the tonsils and thymus was reported in more detailed examinations. However, as the age progresses, it has been determined that the immune system weakens with the loss of telomere (11). The aim of this study is to compare the paraoxonase, telomerase enzymes and HDL values in the blood serum of obese and non-obese cats to determine the possible relationship between them.

\section{MATERIAL and METHODS}

Calısmaya This research was carried out on the basis of the permission of Burdur Mehmet Akif Ersoy University Local Animal Ethics Committee dated 18.12.2019 and numbered 593.

Cats of both sexes and different breeds older than 1 year of age constituted the research material. In this study, blood samples were collected from the animals constituting the study group by considering the following criteria.

Blood samples were collected from a total of 25 animals according to the specified criteria. 15 of these samples were collected from obese cats with a body fat ratio of over $30 \%$ and non-obese (control) cats with 10\% body fat below 30\% according to the body fat measurement system. Of the obese group, 8 were male, 7 were female, and their ages ranged from 1 year to 12 years old. 11 were sterilized, 2 were not sterilized, and 2 were unknown. The control group, on the other hand, consisted of 10 cats, 4 females and 6 males, of ideal weight over 1 year old.

\section{Desired clinical signs}

Body Fat Measurement System

Percentage Body fat $=\left(\frac{\frac{\text { ribcage }}{0.7062}}{0.9156}\right)$-LIM

The equation used rib cage circumference and the lower hindlimb measurement (in $\mathrm{cm}$ ).

Rib cage value: The circumference of the rib cage passing over the 9th rib

Leg index value: Distance between patella and calcaneal lump

Ideal weight cats have a body fat ratio of $15-30 \%$,

Those who are considered to be extremely weak, have less than $20 \%$ fat,

Those who were overweight, that is obese, were evaluated as cats with $30 \%$ and above body fat (12).

Blood samples from all cats were taken from vena Cephalica antebrachii into negative pressure tubes using a disposable sterile syringe. Silicone-based plastic tubes $(5 \mathrm{ml})$ with clot activator were used for serum samples. The collected blood samples were first kept in a portube for 30 minutes, allowing the blood to clot. Then, their serums were removed in a centrifuge device at $4000 \mathrm{rpm}$ for 10 minutes. Serum samples were transferred to eppendorf tubes $(1.5 \mathrm{ml})$ with the help of automatic pipette. The tubes, which were recorded by writing sample numbers on them, were stored at $-20^{\circ} \mathrm{C}$ until serological analysis.

Paraoxonase and telomerase enzymes in blood serum were measured by ELISA (Enzyme-Linked Immunosorbent Assay) method. Cat Telomerase ELISA Kit and Cat Paraoxonase ELISA Kits (BTLAB, CHINA) were used in the study. In biochemical analysis, HDL values were measured with Gesan Chem 200-1102422 (Italy) autoanalyzer device.

Table 1. Paraoxonase, telomerase and HDL values in obese and control groups.

\begin{tabular}{llll}
\hline & $\begin{array}{l}\text { Group 1 }(\mathbf{n}=\mathbf{1 0}) \\
\bar{x} \pm s s\end{array}$ & $\begin{array}{l}\text { Group 2 }(\mathbf{n}=15) \\
\bar{x} \pm s s\end{array}$ & P \\
\hline Paraoxonase (ng/ml) & $15.07 \pm 3.44^{\mathrm{a}}$ & $9,754 \pm 2.05^{\mathrm{b}}$ & 0.001 \\
& & & \\
Telomerase (ng/ml) & $2.14 \pm 1.32^{\mathrm{a}}$ & $0.52 \pm 0.41^{\mathrm{b}}$ & 0.001 \\
HDL $(\mathrm{mg} / \mathrm{dl})$ & $135.30 \pm 45.01^{\mathrm{a}}$ & $85,73 \pm 29.12^{\mathrm{b}}$ & 0.008 \\
\hline
\end{tabular}

There is a statistical difference between those containing different letters $(p<0.05)$. 


\section{Statistical analysis}

The findings obtained were evaluated using IBM SPSS 22.0 for Windows package program. Shapiro-Wilk test was used in the compliance of the data to normal distribution. Due to the normal distribution of the data, pairwise group comparisons were determined with the Independent-Samples T-test (Student's t-test).

\section{RESULTS}

In Group 1 (control) and Group 2 (obese), a statistical (p $<0.001$ ) difference was found in the comparison of the measurement of the paraoxonase value between the groups.A statistical $(p<0.001)$ difference was found in the comparison of the measurement of telomerase value between groups in Group 1 and Group 2. A statistical ( $\mathrm{p}<0.008$ ) difference was found in the comparison of the measurement of HDL value between groups in Group 1 and Group 2 (Table 1).

\section{DISCUSSION}

Most of the adult domestic cat population is overweight or obese. It is accepted that obesity in cats makes them more susceptible to diseases such as lower urinary tract disease, lameness, hepatic lipidosis, non-allergic skin diseases and diabetes mellitus (13).

Paraoxonase 1 (PON1) is an enzyme that protects HDL from peroxidation and has anti-inflammatory properties as it reduces the production of pro-inflammatory mediators. PON1 is mainly expressed in the liver and is transported within HDL-bound plasma (14).

Tvarijonaviciute et al. (15) evaluated various circulating inflammatory and metabolic biochemical analyzes before and after weight loss in obese cats. No difference was observed in PON-1 activity before and after weight loss, although lower baseline PON-1 activity has been reported to be associated with weight loss program failure.

As a result of the study, it was observed that before weight loss, PON-1 activity, adiponectin concentration, and IGF-1 concentration were lower in cats that could not complete weight loss, while glucose concentration was higher than in cats who lost weight.

In a study conducted in humans, PON1 value was evaluated in the blood serum of obese and severely obese, moderately obese, overweight and normal weight female patients. The PON1 levels of the patients in the obese and severely obese group were found to be significantly different from the values of the control group, overweight and moderately obese patients. In patients with the most severe obesity, PON1 activity was found to be significantly lower than controls and all other groups. It has been reported that individuals with low PON1 activity have a higher risk of developing disease caused by oxidative stress and lipid peroxidation than individuals with high PON1 activity (16). It has been reported that PON1 is inactivated in cases of excessive oxidative stress[6]. According to the results of our study, a statistical difference was found between the serum paraoxonase enzyme values of obese cats and non-obese cats in the control group, and the paraoxonase values of obese cats were found to be lower than the control group. The result of our study is similar to the study in obese people mentioned above, and it was thought that the reason for the low PON1 level in obese cats may be due to lipid peroxidation, decreased PON1 activity as a result of change in PON1 synthesis, or changes in HDL structure and composition.

Pehlivan (17) evaluated telomerase activity in obese people in his study. He found that telomerase activity was decreased in the obese group between the obesity group and the control group. He reported that the comorbidities brought about by obesity pose a risk for aging.

In a study conducted in cats with chronic kidney failure, low telomerase activity was reported in kidney tissue.

In contrast to kidney tissue, a statistically significant increase in telomerase activity was observed in the liver tissue of cats with chronic renal failure, although all liver samples were histopathologically normal and no cat had elevated liver enzymes or serum biochemical parameters. It has been reported that systemic oxidative stress observed in cats with chronic kidney failure may cause increased liver telomerase levels by modulating antioxidant mechanisms in the liver (18).

According to the results of our study, a statistically significant decrease was found between the serum telomerase enzyme activity values of obese cats and non-obese cats in the control group. This result is similar to the study conducted by Pehlivan[17] on humans, and considering the decrease in telomerase enzyme and low PON1 level may be due to lipid peroxidation, it supports the idea that obesity may increase the risk of tissue aging.

HDL serves to remove cholesterol from peripheral cells and macrophages to the liver. The reverse cholesterol transport process is considered to be antiatherogenic in humans $(19,20)$. It has been reported that HDL is the main lipoprotein class in healthy cats and is the most important carriers from peripheral tissues where cholesterol is broken down and excreted, from the liver (21).

In one study, the effects of long-term obesity and different diets on plasma lipids were examined in 12 lean and 12 obese cats. HDL concentration was observed lower in the obese group and consisted mainly of small size particles. In the obese group, it was found to have higher plasma unesterified fatty acids and triglycerides, as well as VLDLs mainly composed of medium-sized particles (22). The results of the study are similar to the HDL results in our study. In a study investigating lipoprotein, oxidative stress and HDL-PON activity among healthy and obese people; It has been reported that HDL-PON activity is significantly lower in obese individuals compared to the control group. It has been suggested that changes in HDL content reduce the enzyme activity by affecting paraoxonase binding to the HDL surface (23). Another study in humans found that HDL-PON activity decreased in obese patients. It has been reported that the decrease in PON1 activity and the compositional and functional changes of HDL in patients 
with different degrees of obesity may contribute to increased oxidation of cells in the artery wall, increased inflammation in the vessel wall, and increased atherosclerosis (24). According to the results of our study, a statistical difference was found between the serum HDL values of obese cats and non-obese cats in the control group. HDL values of obese cats were significantly lower compared to the control group. The results of our study were similar to the studies Ferretti et al. Conducted in obese people in 2005 and 2010. According to Ferretti et al. (24), it has been reported that HDL has less protective effect and may be effective in accelerating cellular oxidative damage and arteriosclerosis in obesity. In addition, low serum HDL levels in obese cats may be caused by HDL carrying cholesterol from tissues to the liver.

\section{CONCLUSION}

In this study, paraoxonase, telomerase enzymes and serum HDL levels were compared between obese and non-obese cats. According to our results, paraoxonase enzyme ( $\mathrm{ng} / \mathrm{ml}$ ) was found in the obese group $(9.754 \pm 2.05)$ and in the control group $(15.07 \pm 3.44)(\mathrm{p}<0.001)$. Telomerase enzyme $(\mathrm{ng} / \mathrm{ml})$ was found in the obese group $(0.52 \pm 0.41)$ and in the control group $(2.14 \pm 1.32)(\mathrm{p}<0.001)$. Serum HDL values $(\mathrm{mg} / \mathrm{dl})$ were found in the obese group $(85.73 \pm 29.12)$ and in the control group $(135.30 \pm 45.01)(\mathrm{p}<0.008)$.

The differences between the two groups in three parameters were found to be statistically significant when compared among themselves. A significant decrease was observed in the obese group compared to the control group in all three parameters. As a result; paraoxonase and telomerase enzymes which are parameters of oxidative stress and are known to decrease in inflammation, were also found to be decreased in obese cats. The fact that HDL values are lower than the control group is an indicator that there are diseases that occur together with obesity.

\section{DECLARATIONS}

\section{Conflict of Interest}

The authors declare that there have no conflict of interests.

\section{Author Contributions}

The design of the study and evaluation of the results were executed by the contribution of T. DAG and S. ŞAHINDURAN. All authors also contributed to the preparation of the manuscript.

\section{Acknowledgments}

This study was supported by Mehmet Akif Ersoy University Scientific Research Projects Commission (Project No: 0626YL-20).

\section{REFERENCES}

1. Wall M, Cave NJ, Vallee E. Owner and cat-related risk factors for feline overweight or obesity. Front vet Sci. 2019; $6,266$.

2. Kobayashi M, Okada Y, Ueno H, Mizorogi T, Ohara K,
Kawasumi K, Arai T. Effects of Supplementation with Anti-Inflammatory Compound Extracted from Herbs in Healthy and Obese Cats. Vet Med Res Rep. 2020; 11, 39.

3. Corbee RJ. Obesity in show cats. J Anim Physiol An. 2014; 98 (6): 1075-1080.

4. Leray V, Freuchet B, Le Bloc'h J, Jeusette I, Torre C. Nguyen P., Effect of citrus polyphenol and curcumin-supplemented diet on inflammatory state in obese cats. Br J Nutr. 2011; 106, S198 - S201.

5. Juretic D, Tadijanovic M, Rekic B, Simean-Rudolf V, Reiner E, Baricic M. Serum paraoxonase activities in hemodialyzed uremic patients: cohort study. Croatian Med J. 2001; 42, 146-150.

6. Özgün E. İsoproterenol ile deneysel miyokart infarktüsü oluşturulan sıçanlarda melatoninin serum paraoksonaz aktivitesine etkisi. Trakya Üniversitesi Tıp Fakültesi Tıbbi Biyokimya Anabilim Dalı, Edirne/ Türkiye, 2013.

7. Abdelouahed K, Kamtchueng SO, Ikhlef S, Berrougui H. The role of paraoxonase 1 in regulating HDL functionality during aging. Can J Physiol Pharmacol. 2017; 95 (10): 1254-1262.

8. Kotani K, Sakane N, Sano Y, et al. Changes on the physiological lactonase activity of serum paraoxonase 1 by a diet intervention for weight loss in healthy overweight and obese women. J Clin Biochem Nutr. 2009; 45, 329-334.

9. Costa LG, Cole TB, Furlong CE. Paraoxonase (PON1) and Detoxication of Nerve Agents. Handbook of Toxicology of Chemical Warfare Agent. 2015; 1089-1098.

10. Tiryakioğlu A, Özkan M, Kayım S, Bağc1 Ö, Çeviker K, Tatar B, Yazkan R, Erdemoğlu E. Kanser Tanı ve Tedavisinde DNA'ya Yönelik Güncel Yaklaşımlar: Telomeraz/Tert. Mühendis Bilim Tasar Derg. 2016; 4(2): 125-131.

11. Andrews NP, Fujii H, Goronzy JJ, Weyand CM. Telomerase and immunological diseases of aging. Gerontology. 2010; 56, 390-403.

12. Hawthorne AJ, Butterwick RF. The feline body mass index $\neg$ a simple measure of body fat content in cats. WALTHAM Foc. 2000; 10(1): 32- 733 .

13. Bjornvad CR, Nielsen DH, Armstrong PJ, McEvoy F, Hoelmkjaer KM, Jensen KS, Kristensen AT. Evaluation of a nine-point body condition scoring system in physically inactive pet cats. AJVR. 2011; 72 (4): 433-437.

14. Rossi G, Giordano A, Pezzia F, Kjelgaard $\square$ Hansen M, Paltrinieri S. Serum paraoxonase 1 activity in dogs: preanalytical and analytical factors and correlation with $C \square$ reactive protein and alpha $\square 2 \square$ globulin. Vet Clin Pathol. 2013; 42(3): 329-341.

15. Tvarijonaviciute A, Ceron JJ, Holden SL, Morris PJ, Biourge V, German AJ. Effects of weight loss in obese cats on biochemical analytes related to inflammation and glucose homeostasis. Domes Anim Endocrinol. 2012; 42(3): 129-141. 
16. Cervellati C, Bonaccorsi G, Trentini A, Valacchi G, Sanz JM, Squerzanti M, Parladori R. Paraoxonase, arylesterase and lactonase activities of paraoxonase1 (PON1) in obese and severely obese women. Scand J Clin Lab Inv. 2018; 78(1-2): 1824.

17. Pehlivan E. Obez Hastalarda Klotho ve Telomeraz İlişkisinin Değerlendirilmesi. Ege Ünivers. Tıp Fakül. İç Hast. Anabilim Dalı. İzmir/ Türkiye, 2017.

18. Quimby JM, Maranon DG, Battaglia CL, McLeland SM, Brock WT, Bailey SM. Feline chronic kidney disease is associated with shortened telomeres and increased cellular senescence. Am J Physiol Renal Physiol. 2013; 305(3): F295- F303.

19. Minamoto T. Lipoprotein Profiling in Dogs and Cats with Gastrointestinal Disease or Hepatic Disease. Doctoral dissertation, Texas A \& M University, 2018.

20. Minamoto T, Walzem RL, Hamilton AJ, Hill SL, Payne HR, Lidbury JA, Steiner JM. Altered lipoprotein profiles in cats with hepatic lipidosis. J Feline Med Surg. 2019; 21(4): 363-372.

21. Wisselink MA, Koeman JP, Wensing T, De Bruijne J, Willemse T. Hyperlipoproteinaemia associated with atherosclerosis and cutaneous xanthomatosis in a cat. Vet Q. 1994; 16(4): 199-202.

22. Jordan E, Kley S, Le NA, Waldron M, Hoenig M. Dyslipidemia in obese cats. Domest Anim Eddocrinol. 2008; 35(3): 290-299.

23. Ferretti G, Bacchetti T, Moroni C, Savino S, Liuzzi A, Balzola F, Bicchiega V. Paraoxonase activity in high-density lipoproteins: a comparison between healthy and obese females. J Clin Endocrinol Metab. 2005; 90 (3):1728-1733.

24. Ferretti G, Bacchetti T, Masciangelo S, Bicchiega V. HDL $\square$ paraoxonase and membrane lipid peroxidation: a comparison between healthy and obese subjects. Obesity. 2010; 18(6): 1079-1084. 